\title{
Temperature Sensitivity of Nitrogen Dynamics of Agricultural Soils of the United States
}

\author{
Amitava Chatterjee1, Alexsandro Felipe de Jesus', Diksha Goyal1, Sailesh Sigdel1, \\ Larry J. Cihacek ${ }^{1}$, Bhupinder S. Farmaha ${ }^{2}$, Sindhu Jagadamma3 ${ }^{3}$ Lakesh Sharma4, Daniel S. Long5 \\ ${ }^{1}$ Department of Soil Science, North Dakota State University, Fargo, ND, USA \\ ${ }^{2}$ Edisto Research and Education Center, Clemson University, Blackville, SC, USA \\ ${ }^{3}$ Ecology and Evolutionary Biology, The University of Tennessee, Knoxville, TN, USA \\ ${ }^{4}$ Soil and Water Sciences, University of Florida, Gainsville, FL, USA \\ ${ }^{5}$ Soil and Water Conservation Research, USDA-ARS, Pendleton, OR, USA \\ Email: amitava.chatterjee@ndsu.edu,bfarmah@clemson.edu, sjagada1@tennessee.edu, lakesh.sharma@ufl.edu, \\ junco.hyemalis@protonmail.com
}

How to cite this paper: Chatterjee, A., De Jesus, A.F., Goyal, D., Sigdel, S., Cihacek, L.J., Farmaha, B.S., Jagadamma, S., Sharma, L. and Long, D.S. (2020) Temperature Sensitivity of Nitrogen Dynamics of Agricultural Soils of the United States. Open Journal of Soil Science, 10, 298-305. https://doi.org/10.4236/ojss.2020.107016

Received: July 1, 2020

Accepted: July 27, 2020

Published: July 30, 2020

Copyright $\odot 2020$ by author(s) and Scientific Research Publishing Inc. This work is licensed under the Creative Commons Attribution International License (CC BY 4.0).

http://creativecommons.org/licenses/by/4.0/

\section{Open Access}

\begin{abstract}
Soil temperature controls gaseous nitrogen losses through nitrous oxide $\left(\mathrm{N}_{2} \mathrm{O}\right)$ and ammonia $\left(\mathrm{NH}_{3}\right)$ fluxes. Eight surface soils from agricultural fields across the United States were incubated at $10^{\circ} \mathrm{C}, 20^{\circ} \mathrm{C}$, and $30^{\circ} \mathrm{C}$, and $\mathrm{N}_{2} \mathrm{O}$ and $\mathrm{NH}_{3}$ flux were measured twice a week for 91 and $47 \mathrm{~d}$, respectively. Changes in cumulative $\mathrm{N}_{2} \mathrm{O}$ and $\mathrm{NH}_{3}$ flux and net $\mathrm{N}$ mineralization at three temperatures were fitted to calculate $\mathrm{Q}_{10}$ using the Arrhenius equation. For the majority of soils, $\mathrm{Q}_{10}$ values for the $\mathrm{N}_{2} \mathrm{O}$ loss ranged between 0.23 and 2.14, except for Blackville, North Carolina (11.4) and Jackson, Tennessee (10.1). For $\mathrm{NH}_{3}$ flux, $\mathrm{Q}_{10}$ values ranged from 0.63 (Frenchville, Maine) to 1.24 (North Bend, Nebraska). Net soil N mineralization- $\mathrm{Q}_{10}$ ranged from 0.96 to 1.00. Distribution of soil organic carbon and total soil $\mathrm{N}$ can explain the variability of $\mathrm{Q}_{10}$ for $\mathrm{N}_{2} \mathrm{O}$ loss. Understanding the $\mathrm{Q}_{10}$ variability of soil $\mathrm{N}$ dynamics will help us to predict the $\mathrm{N}$ loss.
\end{abstract}

\section{Keywords}

Arrhenius Equation, Soil Organic Carbon, Inorganic Nitrogen, Gaseous Losses of Nitrogen

\section{Introduction}

Gaseous losses of nitrogen $(\mathrm{N})$, nitrous oxide $\left(\mathrm{N}_{2} \mathrm{O}\right)$ denitrification and ammonia $\left(\mathrm{NH}_{3}\right)$ volatilization, reduce fertilizer- $\mathrm{N}$ use efficiency and may cause environmental degradation [1]. Global estimates suggest approximate $\mathrm{N}$ losses of 
$0.5 \%-2 \%$ and $10 \%-18 \%$ of initial $\mathrm{N}$ content through denitrification and volatilization respectively [2] [3]. Lack of studies regarding the temperature sensitivity of gaseous losses of $\mathrm{N}$ makes it difficult to model how changing spatial variability of crop, soil, and water management practices will impact the environment [4].

Soil temperature has significant control over $\mathrm{N}$ mineralization [5], denitrification [6], and volatilization [7]. Temperature sensitivity of the biological processes is generally expressed as the function of the increase in metabolic rate with $10^{\circ} \mathrm{C}$ rise in temperature or $\mathrm{Q}_{10}$. For most modeling approaches, $\mathrm{Q}_{10}$ value was assumed to be close to 2, irrespective of soil type, climate and management practices [6] [8]. However, researchers reported a wide range of $Q_{10}$ values ranging from 1 to 17.1 for denitrification [9], 1.4 to 5.0 for volatilization [10], and 1.67 to 2.43 for soil $\mathrm{N}$ mineralization [11].

A laboratory incubation study was conducted to determine the $\mathrm{Q}_{10}$ value of $\mathrm{N}_{2} \mathrm{O}$ and $\mathrm{NH}_{3}$ flux, volatilization and $\mathrm{N}$ mineralization for eight soil samples collected across agricultural systems of the United States. If $\mathrm{Q}_{10}$ value is not affected by climate, soil type, or cropping system, measurements of $\mathrm{Q}_{10}$ will be equal to 2 regardless of soil evaluated. To test this hypothesis, we measured cumulative $\mathrm{N}_{2} \mathrm{O}$ and $\mathrm{NH}_{3}$ flux and net $\mathrm{N}$ mineralization with incubation temperature, and temperature sensitivity or $\mathrm{Q}_{10}$ of $\mathrm{N}_{2} \mathrm{O}$ and $\mathrm{NH}_{3}$ flux and net $\mathrm{N}$ mineralization at $10^{\circ} \mathrm{C}, 20^{\circ} \mathrm{C}$, and $30^{\circ} \mathrm{C}$. We then calculated the temperature sensitivity, or $\mathrm{Q}_{10}$ of $\mathrm{N}_{2} \mathrm{O}$ and $\mathrm{NH}_{3}$ flux and net $\mathrm{N}$ mineralization for these agricultural soils.

\section{Materials and Methods}

Surface soil samples of $0-15 \mathrm{~cm}$ depth were collected from eight agricultural fields across the United States (Figure 1, Table 1). Soil samples were air-dried

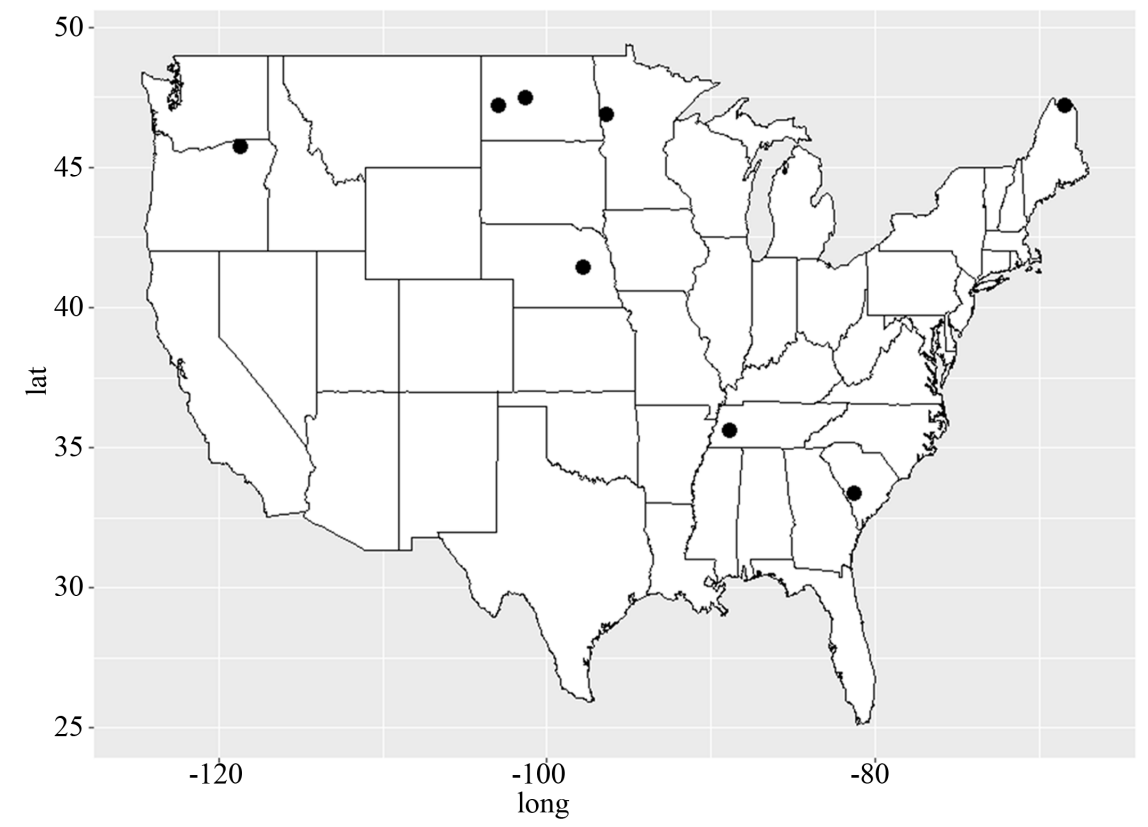

Figure 1. Site locations for surface soil samples used to measure the temperature sensitivity of nitrogen loss. 
Table 1. Site description, crop rotation, tillage management, basic soil properties, and annual average weather data of collected soils used for the incubation study.

\begin{tabular}{|c|c|c|c|c|c|c|c|c|c|c|c|c|c|c|}
\hline 营 & 旁 & 苞 & 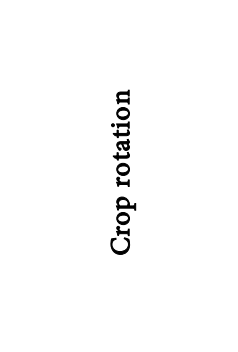 & 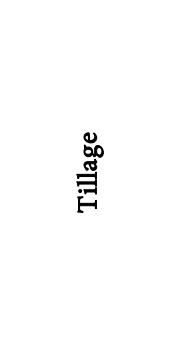 & 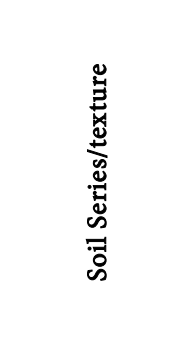 & 窝 & 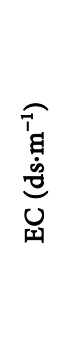 & 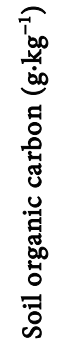 & 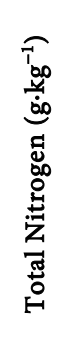 & 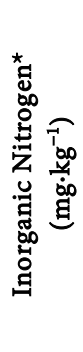 & 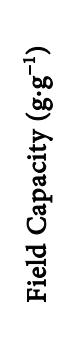 & 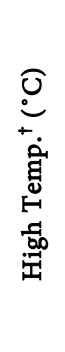 & 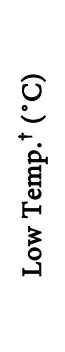 & 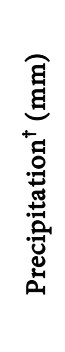 \\
\hline Maine & Frenchville & $\begin{array}{l}\text { N 47.2161028, } \\
\text { W -68.412227 }\end{array}$ & Potato-grain-clover & Conventional & $\begin{array}{c}\text { Plaisted } \\
\text { gravelly loam }\end{array}$ & 5.8 & 0.48 & 20 & 2.10 & 31.9 & 0.260 & 8.3 & -1.1 & 850 \\
\hline Tennessee & Jackson & $\begin{array}{l}\text { N 35.6230, } \\
\text { W }-88.8465\end{array}$ & $\begin{array}{l}\text { Continuous } \\
\text { Cotton }\end{array}$ & No-tillage & $\begin{array}{l}\text { Lexington } \\
\text { silt loam }\end{array}$ & 5.4 & 0.32 & 10 & 1.40 & 47.8 & 0.261 & 21.6 & 9.4 & 1375 \\
\hline $\begin{array}{l}\text { South } \\
\text { Carolina }\end{array}$ & Blackville & $\begin{array}{c}\text { N 33.346539, } \\
\text { W -81.297283 }\end{array}$ & $\begin{array}{l}\text { Continuous } \\
\text { Corn }\end{array}$ & Strip-tillage & $\begin{array}{c}\text { Duplin } \\
\text { sandy loam }\end{array}$ & 5.6 & 0.09 & 5.0 & 0.60 & 14.8 & 0.053 & 25.6 & 11 & 1198 \\
\hline Minnesota & Downer & $\begin{array}{c}\text { N 46.8655, } \\
\text { W -96.396806 }\end{array}$ & $\begin{array}{l}\text { Sugarbeet- } \\
\text { Corn }\end{array}$ & Conventional & $\begin{array}{l}\text { Lamoure } \\
\text { silt loam }\end{array}$ & 8.1 & 0.16 & 15.5 & 1.60 & 14.1 & 0.118 & 11.6 & 0 & 573 \\
\hline $\begin{array}{l}\text { North } \\
\text { Dakota }\end{array}$ & Bismarck & $\begin{array}{c}\mathrm{N} 47.4630, \\
\mathrm{~W}-101.2772\end{array}$ & $\begin{array}{c}\text { Spring } \\
\text { Wheat-Soybean }\end{array}$ & No-tillage & $\begin{array}{l}\text { Wilton } \\
\text { silt loam }\end{array}$ & 7.3 & 0.17 & 21.7 & 2.30 & 32.6 & 0.265 & 12.8 & -1 & 453 \\
\hline $\begin{array}{l}\text { North } \\
\text { Dakota }\end{array}$ & Dickinson & $\begin{array}{c}\text { N 47.19314, } \\
\text { W - } 102.89661\end{array}$ & $\begin{array}{c}\text { Continuous } \\
\text { Wheat }\end{array}$ & No-tillage & $\begin{array}{l}\text { Vebar-Parshall } \\
\text { fine sandy loam }\end{array}$ & 5.2 & 0.14 & 17.0 & 1.70 & 16.9 & 0.239 & 12.8 & -1 & 400 \\
\hline Nebraska & North Bend & $\begin{array}{c}\text { N41.429308, } \\
\text { W -97.794056 }\end{array}$ & Corn-soybean & No-tillage & $\begin{array}{l}\text { Nora silty } \\
\text { clay loam }\end{array}$ & 6.7 & 0.10 & 15.4 & 1.80 & 23.3 & 0.120 & 16.1 & 3.9 & 763 \\
\hline Oregon & Pendleton & $\begin{array}{c}\text { N 45.718439, } \\
\text { W - } 118.626883\end{array}$ & $\begin{array}{c}\text { Fallow-Winter } \\
\text { Wheat }\end{array}$ & No-tillage & $\begin{array}{c}\text { Walla Walla } \\
\text { silt loam }\end{array}$ & 6.0 & 0.40 & 12.0 & 1.20 & 29.8 & 0.291 & 17.2 & 5.0 & 322 \\
\hline
\end{tabular}

${ }^{*}$ Inorganic nitrogen-ammonium $\left(\mathrm{NH}_{4}^{+}\right)$and nitrate $\left(\mathrm{NO}_{3}^{-}\right)$concentrations; ${ }^{\dagger}$ Annual average.

and grounded to pass through $2 \mathrm{~mm}$ sieve. Soil $\mathrm{pH}$ and electrical conductivity were measured of 1:2.5 soil slurry with Oakton PC700 pH and EC meter. Soil organic carbon and total $\mathrm{N}$ were determined by automated dry combustion method [12]. Soil inorganic $\mathrm{N}$ concentration was measured by extracting soils with $2 \mathrm{M} \mathrm{KCl}$ and determining $\mathrm{NH}_{4}^{+}$and $\mathrm{NO}_{3}^{-}$concentrations using Timberline Ammonia (TL-2800) analyzer (Boulder, CO). Field capacity (at 0.33 bar) was determined using the pressure plate apparatus as described by [13].

Soil samples were incubated at $10^{\circ} \mathrm{C}, 20^{\circ} \mathrm{C}$ and $30^{\circ} \mathrm{C}$ using an incubation chamber. For incubation, $30 \mathrm{~g}$ soils moistened at field capacity level were placed in a 1-L clear jar (Table 1$)$. One granule of urea $(\sim 40 \mathrm{mg})$ was weighed and added on the soil surface. Water loss was compensated by adding water based on the difference in jar weight. The cap of jar was fitted with the gas sampling port (butyl rubber septum) to sample headspace air and a metal wire attached to the cap to hold a $50 \mathrm{~mL}$ clear plastic beaker filled with $15 \mathrm{~mL}$ of $0.5 \mathrm{M}$ phosphoric acid to trap $\mathrm{NH}_{3}$ emission from soils. A total of 36 jars (8 sites $\times 4$ replication +4 blanks) were incubated for 91 days at each temperature. Headspace air was sampled approximately on days $1,3,6,9,12,16,19,23,26,30,34,37,40,44,47,50$, 
56, $6370,77,84$, and 91 for $\mathrm{N}_{2} \mathrm{O}$ flux and until day 47 for $\mathrm{NH}_{3}$ flux. On each observation day, first headspace air sample was collected using a $10 \mathrm{~mL}$ syringe, followed by the removal of the acid trap, then the jar was aerated for half an hour, and soil moisture was readjusted to field capacity and then jars were capped and returned to the incubator.

The $\mathrm{N}_{2} \mathrm{O}$ concentration of headspace air samples was determined using a Shimadzu GC-2014 (Shimadzu Scientific Instruments Inc., Houston, TX) fitted with $63 \mathrm{Ni}$-electron capture detector. The GC oven was operated at $80^{\circ} \mathrm{C}$ and ECD was operated at $325^{\circ} \mathrm{C}$, and $\mathrm{N}_{2}$ carrier gas was supplied at 20 PSI. Instrument was calibrated using analytical $\mathrm{N}_{2} \mathrm{O}$ standards of: $0,1,5,50,100,500$, and $1000 \mu \mathrm{mole} \cdot \mathrm{ml}^{-1}$. Compound peak was recorded and analyzed with Lab Solutions software (LabSolutions, Atlanta, Georgia). The $\mathrm{N}_{2} \mathrm{O}$ concentration was converted to mass unit using ideal gas equations and expresses as micrograms of $\mathrm{N}_{2} \mathrm{O}$ produced between sampling days per kg of soil [14] [15]. Soil-emitted $\mathrm{NH}_{3}$ was trapped and replaced with fresh phosphoric acid solution at the same intervals as $\mathrm{N}_{2} \mathrm{O}$ flux measured. The collected acid solution was extracted with $25 \mathrm{~mL}$ of $2 \mathrm{M} \mathrm{KCl}$ with half an hour shaking the mixture in reciprocal shaker [14]. The extracts were then analyzed for $\mathrm{NH}_{4}^{+}$concentrations using an automated ammonia analyzer (TL 2800, Timberline Instruments, Boulder, CO). The amount of volatilization during each incubation interval was expressed in the form of microgram $\mathrm{NH}_{3}$ per gram soil. Cumulative $\mathrm{NH}_{3}-\mathrm{N}$ loss (mg $\mathrm{NH}_{3}-\mathrm{N}$ kg soil) during the entire incubation was computed from the summation of $\mathrm{NH}_{3}$ emission during all sampling periods.

After 91 days of incubation, soil samples from each jar were analyzed for inorganic $\mathrm{N}$ concentration $\left(\mathrm{NH}_{4}^{+}\right.$and $\left.\mathrm{NO}_{3}^{-}\right)$for each incubation temperature. Percent of net $\mathrm{N}$ mineralized during incubation was calculated using the following equation.

$$
\text { Net } \mathrm{N} \text { mineralization } \%=\frac{(\text { Initial soil- } \mathrm{N}+\text { Urea-N })-\text { Final soil-N }}{\text { Initial soil- } \mathrm{N}+\text { urea-N }} \times 100
$$

Urea- $\mathrm{N}$ was calculated by multiplying 0.46 with the weight of urea granule. The effect of temperature on of $\mathrm{N}_{2} \mathrm{O}$ and $\mathrm{NH}_{3}$ flux, and net $\mathrm{N}$ mineralization\% was evaluated by determination of the parameter $E_{a}$ in the logarithmic form of the Arrhenius equation:

$$
\ln (k)=\ln (A)-E_{a} / R T
$$

where $k$ is the rate of $\mathrm{N}_{2} \mathrm{O}$ and $\mathrm{NH}_{3}$ flux, $A$ is the preexponential constant, $E_{a}$ is the activation energy $\left(\mathrm{kJ} \cdot \mathrm{mol}^{-1}\right), R$ is the gas constant $\left(8.314 \mathrm{~J} \cdot \mathrm{mol}^{-1} \cdot \mathrm{K}^{-1}\right)$ and $T$ is the absolute temperature in Kelvin $(\mathrm{K})$. The activation energy was calculated from the slope $\left(-E_{a} / R\right)$ of the linear regression in the plot of $\log$ of $\mathrm{N}_{2} \mathrm{O}$ and $\mathrm{NH}_{3}$ flux rate vs. the inverse incubation temperature, $\mathrm{Q}_{10}$ value was calculated as

$$
\begin{aligned}
& \mathrm{Q}_{10}=\exp \left[\left(E_{a} / R\right)\left(1 /\left(T_{1}+10\right)-1 / T_{1}\right)\right] \\
& T_{1}=293^{\circ} \mathrm{C} \text { equivalent to } 20^{\circ} \mathrm{C}
\end{aligned}
$$

Cumulative $\mathrm{N}_{2} \mathrm{O}$ and $\mathrm{NH}_{3}$ flux at each incubation temperature, net $\mathrm{N}$ miner- 
alization percentage and $\mathrm{Q}_{10}$ values were compared for different sites using the completely randomized design (CRD) with a mean separation at $95 \%$ significance level using SAS 9.4. For each site, incubation temperature effect on cumulative $\mathrm{N}_{2} \mathrm{O}$ and $\mathrm{NH}_{3}$ flux were also determined using CRD with a mean separation at $95 \%$ significance level. Correlation coefficient and regression analyses were conducted to determine the relationship between soil properties and $\mathrm{Q}_{10}$ values using SAS 9.4.

\section{Results and Discussion}

Cumulative $\mathrm{N}_{2} \mathrm{O}$ flux increased with temperature for most soils except those collected from Frenchville, Bismarck, and Pendleton (Table 2). At $10^{\circ} \mathrm{C}$, soils from Pendleton had the highest cumulative flux, but statistically similar to Frenchville and Bismarck; whereas, the lowest value was observed for soils from Blackville. At $20^{\circ} \mathrm{C}$, Pendleton soils had the highest cumulative $\mathrm{N}_{2} \mathrm{O}$ flux, similar to Frenchville, and the lowest value was observed for soils from North Bend. At $30^{\circ} \mathrm{C}$, Frenchville had the highest cumulative flux, significantly higher than rest, and the lowest value was found for soils from Dickinson. Temperature sensitivity, $\mathrm{Q}_{10}$ values of cumulative $\mathrm{N}_{2} \mathrm{O}$ flux ranged between 0.23 at Bismarck, and 11.4 at Blackville. Soils from Jackson, $\mathrm{TN}$ had $\mathrm{Q}_{10}$ value of 10.1, statistically similar to Blackville. The rest of the six sites had similar $\mathrm{Q}_{10}$ values ranging between 0.23 2.14. Blackville and Jackson had lower soil organic $C$ than other sites; low soil organic $\mathrm{C}$ or high recalcitrance of substrates should generally be more sensitive to temperature changes than that of more labile substrates, which could, in turn, increase the $\mathrm{Q}_{10}$ value. Researchers have also found that additions of $\mathrm{C}$ and $\mathrm{N}$ substrates reduced $\mathrm{Q}_{10}$ of $\mathrm{N}_{2} \mathrm{O}$ due to increased soil microbial $\mathrm{C}$ and $\mathrm{N}$ use efficiency [15].

Increasing temperature reduced cumulative $\mathrm{NH}_{3}$ flux except for Downer, and North Bend, sites (Table 2). Soils from Blackville had the highest and Frenchville, had the lowest cumulative $\mathrm{NH}_{3}$ flux at all three temperatures. Soils from North Bend had the highest $\mathrm{Q}_{10}$ value for $\mathrm{NH}_{3}$, but similar to Downer, and Pendleton. For the rest of the sites, $\mathrm{Q}_{10}$ value for $\mathrm{NH}_{3}$ ranged from 0.63 to 0.70 . Most researchers observed an increase in volatilization loss with temperature [7] [16]. Researchers [7] reported a two-fold increase when temperature increased from $5^{\circ} \mathrm{C}$ to $25^{\circ} \mathrm{C}$ but a threefold when temperature increased from $25^{\circ} \mathrm{C}$ to $45^{\circ} \mathrm{C}$. They concluded that greatly enhanced $\mathrm{NH}_{3}$ volatilization at $45^{\circ} \mathrm{C}$ compared with $25^{\circ} \mathrm{C}$ was related to the inhibition of nitrification at high temperature, which increased the supply of ammoniacal $\mathrm{N}$ for $\mathrm{NH}_{3}$ volatilization for a prolonged time. Our maximum incubation temperature of $\left(30^{\circ} \mathrm{C}\right)$ was comparatively lower than the threshold for the inhibition of nitrification. Further, researcher [17] found that high temperatures $\left(32^{\circ} \mathrm{C}\right)$ increased the initial rates of $\mathrm{NH}_{3}-\mathrm{N}$ loss and they were proportionally reduced at later stages; on the contra-

ry, the lowest temperature $\left(12^{\circ} \mathrm{C}\right)$ resulted in the lowest initial $\mathrm{NH}_{3}-\mathrm{N}$ loss rate but became highest for the last 76 hours. 
Table 2. Control of incubation temperature on mean (standard deviation) of cumulative denitrification, volatilization and nitrogen mineralized from soils collected across agroecosystems of the United States.

\begin{tabular}{|c|c|c|c|c|c|c|}
\hline \multirow{3}{*}{ State } & \multirow{3}{*}{ Site } & \multicolumn{3}{|c|}{ Incubation temperature } & \multirow{2}{*}{\multicolumn{2}{|c|}{$\mathrm{Q}_{10}$}} \\
\hline & & $10^{\circ} \mathrm{C}$ & $20^{\circ} \mathrm{C}$ & $30^{\circ} \mathrm{C}$ & & \\
\hline & & \multicolumn{3}{|c|}{ Cumulative $\mathrm{N}_{2} \mathrm{O}-\mathrm{N}$ flux (mg $\mathrm{kg}^{-1}$ soil) } & & \\
\hline Maine & Frenchville & $12.9^{\mathrm{Aa} \star}(10.6)$ & $13.2^{\mathrm{Aa}}(2.94)$ & $19.1^{\mathrm{Aa}}(2.38)$ & $1.40^{\mathrm{C}}$ & $(0.39)$ \\
\hline Tennessee & Jackson & $0.16^{\mathrm{Bc}}(0.14)$ & $0.89^{\mathrm{Cb}}(0.10)$ & $1.39^{\mathrm{Ca}}(0.49)$ & $10.1^{\mathrm{AB}}$ & $(14.9)$ \\
\hline South Carolina & Blackville & $0.07^{\mathrm{Bb}}(0.05)$ & $4.87^{\mathrm{BCa}}(2.45)$ & $5.39^{\mathrm{Ba}}(1.88)$ & $11.4^{\mathrm{A}}$ & $(5.66)$ \\
\hline Minnesota & Downer & $2.39^{\mathrm{Ba}}(2.22)$ & $5.55^{\mathrm{Ba}}(2.75)$ & $4.63^{\mathrm{Ba}}(2.70)$ & $2.14^{\mathrm{BC}}$ & $(1.65)$ \\
\hline North Dakota & Bismarck & $20.9^{\mathrm{Aa}}(2.60)$ & $1.11^{\mathrm{BCb}}(0.37)$ & $1.25^{\mathrm{Cb}}(0.34)$ & $0.23^{\mathrm{C}}$ & $(0.05)$ \\
\hline North Dakota & Dickinson & $0.36^{\mathrm{Bb}}(0.08)$ & $0.77^{\mathrm{Cab}}(0.30)$ & $0.99^{\mathrm{Ca}}(0.37)$ & $1.65^{\mathrm{C}}$ & $(0.23)$ \\
\hline Nebraska & North Bend & $0.58^{\mathrm{Bb}}(0.10)$ & $0.62^{\mathrm{Cb}}(0.28)$ & $1.50^{\mathrm{Ca}}(0.39)$ & $1.63^{\mathrm{C}}$ & $(0.19)$ \\
\hline Oregon & Pendleton & $27.8^{\mathrm{Aa}}(29.7)$ & $15.7^{\mathrm{Aa}}(7.65)$ & $3.04^{\mathrm{BCa}}(1.95)$ & $0.53^{\mathrm{C}}$ & $(0.42)$ \\
\hline \multirow[t]{2}{*}{$\operatorname{LSD}(0.05)$} & & 16.3 & 4.64 & 2.35 & 8.25 & \\
\hline & \multicolumn{6}{|c|}{ Cumulative $\mathrm{NH}_{3}-\mathrm{N}$ flux ( $\mu \mathrm{g} \cdot \mathrm{g}^{-1}$ soil) } \\
\hline Maine & Frenchville & $14.7^{\mathrm{Da}}(2.39)$ & $9.40^{\mathrm{Eab}}(5.63)$ & $6.62^{\mathrm{Cb}}(5.21)$ & $0.63^{\mathrm{B}}$ & $(0.25)$ \\
\hline Tennessee & Jackson & $51.1^{\mathrm{Bab}}(24.7)$ & $66.8^{\mathrm{ABa}}(36.7)$ & $19.6^{\mathrm{Cb}}(6.12)$ & $0.66^{\mathrm{B}}$ & $(0.23)$ \\
\hline South Carolina & Blackville & $242^{\mathrm{Aa}}(54.2)$ & $85.2^{\mathrm{Ab}}(17.8)$ & $119^{\mathrm{Ab}}(11.5)$ & $0.70^{\mathrm{B}}$ & $(0.09)$ \\
\hline Minnesota & Downer & $48.1^{\mathrm{BCa}}(11.3)$ & $46.7^{\mathrm{BCa}}(4.25)$ & $41.7^{\mathrm{Ba}}(20.5)$ & $0.91^{\mathrm{AB}}$ & $(0.20)$ \\
\hline North Dakota & Bismarck & $29.3^{\mathrm{BCDa}}(7.39)$ & $27.4^{\mathrm{CDEa}}(5.82)$ & $12.9^{\mathrm{Cb}}(4.75)$ & $0.66^{\mathrm{B}}$ & $(0.14)$ \\
\hline North Dakota & Dickinson & $16.1^{\mathrm{CDa}}(3.17)$ & $12.7^{\text {DEab }}(6.53)$ & $7.39^{\mathrm{Cb}}(2.72)$ & $0.66^{\mathrm{B}}$ & $(0.07)$ \\
\hline Nebraska & North Bend & $28.6^{\mathrm{BCDa}}(5.51)$ & $33.1^{\mathrm{CDa}}(13.4)$ & $43.1^{\mathrm{Ba}}(12.1)$ & $1.24^{\mathrm{A}}$ & $(0.22)$ \\
\hline Oregon & Pendleton & $25.0^{\mathrm{BCDab}}(8.02)$ & $44.0^{\mathrm{BCa}}(10.7)$ & $19.8^{\mathrm{Cb}}(16.3)$ & $0.90^{\mathrm{AB}}$ & $(0.53)$ \\
\hline \multirow[t]{2}{*}{$\operatorname{LSD}(0.05)$} & & 32.0 & 23.5 & 16.8 & 0.37 & \\
\hline & \multicolumn{6}{|c|}{$\%$ Nitrogen mineralized } \\
\hline Maine & Frenchville & $78.7^{\mathrm{BCDa}}(2.65)$ & $45.4^{\mathrm{BCb}}(8.35)$ & $79.6^{\mathrm{Ba}}(1.13)$ & $1.00^{\mathrm{A}}$ & $(0.01)$ \\
\hline Tennessee & Jackson & $77.1^{\mathrm{DEa}}(2.24)$ & $28.2^{\mathrm{EFc}}(8.12)$ & $67.7^{\mathrm{Db}}(2.02)$ & $0.97^{\mathrm{CDE}}$ & $(0.01)$ \\
\hline South Carolina & Blackville & $95.8^{\mathrm{Aa}}(0.54)$ & $86.9^{\mathrm{Ab}}(8.91)$ & $91.8^{\mathrm{Aab}}(1.23)$ & $0.99^{\mathrm{AB}}$ & $(0.01)$ \\
\hline Minnesota & Downer & $78.7^{\mathrm{BCDa}}(1.94)$ & $44.9^{\mathrm{CDc}}(4.77)$ & $72.8^{\mathrm{Cb}}(2.47)$ & $0.98^{\mathrm{BC}}$ & $(0.01)$ \\
\hline North Dakota & Bismarck & $80.7^{\mathrm{BCa}}(1.18)$ & $34.4^{\mathrm{DEc}}(8.53)$ & $67.7^{\mathrm{Db}}(2.11)$ & $0.96^{\mathrm{E}}$ & $(0.01)$ \\
\hline North Dakota & Dickinson & $75.2^{\mathrm{Ea}}(1.02)$ & $23.3^{\mathrm{Fc}}(6.14)$ & $62.7^{\mathrm{Eb}}(2.14)$ & $0.96^{\mathrm{E}}$ & $(0.01)$ \\
\hline Nebraska & North Bend & $78.2^{\mathrm{CDa}}(1.77)$ & $34.1^{\mathrm{DEc}}(3.40)$ & $68.2^{\mathrm{Db}}(1.60)$ & $0.97^{\mathrm{DE}}$ & $(0.01)$ \\
\hline Oregon & Pendleton & $81.0^{\mathrm{Ba}}(2.42)$ & $56.1^{\mathrm{Bc}}(8.46)$ & $72.2^{\mathrm{Cb}}(2.53)$ & $0.97^{\mathrm{CD}}$ & $(0.01)$ \\
\hline $\operatorname{LSD}(0.05)$ & & 2.70 & 10.7 & 2.87 & & 0.01 \\
\hline
\end{tabular}

${ }^{*}$ Different capital letters indicate significant differences among sites of the same incubation temperature and different small letters indicate significant differences among temperatures for the same site.

For all sites, net $\mathrm{N}$ mineralization was significantly lower at $20^{\circ} \mathrm{C}$ than $10^{\circ} \mathrm{C}$, and $30^{\circ} \mathrm{C}$, this might be caused due to greater $\mathrm{N}$ immobilization at $20^{\circ} \mathrm{C}$. At all three temperatures, soils from Blackville had the highest, and Dickinson had the 
lowest $\mathrm{N}$ mineralization. Temperature sensitivity or $\mathrm{Q}_{10}$ of net $\mathrm{N}$ mineralization varied from 0.96 to 1.00 . Soils from Frenchville had the highest $Q_{10}$ and soils from Bismarck and Dickinson had the lowest $\mathrm{Q}_{10}$. Other researchers found that $\mathrm{Q}_{10}$ values of $\mathrm{N}$ mineralization varied from 1.03 to 11.89 with an average of 2.21 [11].

The Pearson relationship between soil organic $\mathrm{C}$ and total $\mathrm{N}$ showed a significant negative relationship with $\mathrm{Q}_{10}$ value of $\mathrm{N}_{2} \mathrm{O}$ ( -0.82 and -0.72 , respectively), but did not show any relationship with volatilization or $\mathrm{N}$ mineralization. Linear regression relationships showed that SOC and TN explained the 68 and 52 percent of the variation in $\mathrm{Q}_{10}$ of $\mathrm{N}_{2} \mathrm{O}$. With the rise in each unit $\left(\mathrm{g} \cdot \mathrm{kg}^{-1}\right)$ of SOC and total $\mathrm{N}, \mathrm{Q}_{10}$ value of $\mathrm{N}_{2} \mathrm{O}$ declines by 0.67 and 6.0, respectively. Similarly, other researchers [15] also observed a significant inhibition of pulse $\mathrm{N}_{2} \mathrm{O}$ emissions following $\mathrm{C}$ addition, they hypothesized that $\mathrm{C}$ addition facilitates the microbial growth and in turn accelerates $\mathrm{N}$ immobilization rate.

\section{Conclusion}

This study clearly indicates a wide variation in $\mathrm{Q}_{10}$ for $\mathrm{N}_{2} \mathrm{O}(0.23$ to 11.4$)$, and small variations in $\mathrm{Q}_{10}$ for $\mathrm{NH}_{3}(0.63$ to 1.24$)$ and for the net $\mathrm{N}$ mineralization (0.96 to 1.00). Distribution of soil organic $\mathrm{C}$ can explain the spatial variation of $\mathrm{Q}_{10}$ for $\mathrm{N}_{2} \mathrm{O}$ flux. Future research should explore the spatial variation in $\mathrm{Q}_{10}$ for soils within sensitive regions.

\section{Conflicts of Interest}

The authors declare no conflicts of interest regarding the publication of this paper.

\section{References}

[1] Francis, D.D., Vigil, M.F. and Mosier, A.R. (2008) Gaseous Losses of Nitrogen Other than through Denitrification. In: Schepers, J.S. and Raun, W.R., Eds., Nitrogen in Agricultural Systems, ASA-CSSA-SSSA, Madison, 255-280. https://doi.org/10.2134/agronmonogr49.c8

[2] Hoben, J.P., Gehl, R.J., Millar, N., Grace, P.R. and Robertson, G.P. (2011) Nonlinear Nitrous Oxide $\left(\mathrm{N}_{2} \mathrm{O}\right)$ Response to Nitrogen Fertilizer in On-Farm Corn Crops of the US Midwest. Global Change Biology, 17, 1140-1152. https://doi.org/10.1111/j.1365-2486.2010.02349.x

[3] Pan, B.B., Lam, S.K., Mosier, A., Luo, Y.Q. and Chen, D.L. (2016) Ammonia Volatilization from Synthetic Fertilizers and Its Mitigation Strategies: A Global Synthesis. Agriculture, Ecosystems \& Environment, 232, 283-289. https://doi.org/10.1016/j.agee.2016.08.019

[4] Griffis, T.J., Chen, Z.C., Baker, J.M., Wood, J.D., Millet, D.B., Lee, X.H., Venterea, R.T. and Turner, P.A. (2017) Nitrous Oxide Emissions Are Enhanced in a Warmer and Wetter World. Proceedings of the National Academy of Sciences of the United States of America, 114, 12081-12085. https://doi.org/10.1073/pnas.1704552114

[5] Kladivko, E.J. and Kenney, D.R. (1987) Soil-Nitrogen Mineralization as Affected by Water and Temperature Interactions. Biology and Fertility of Soils, 5, 248-252. 
https://doi.org/10.1007/BF00256909

[6] Stanford, G., Dzienia, S. and Vanderpol, R.A. (1975) Effect of Temperature on Denitrification Rate in Soils. Soil Science Society of America Journal, 39, 867-870. https://doi.org/10.2136/sssaj1975.03615995003900050024x

[7] He, Z.L., Alva, A.K., Calvert, D.V. and Banks, D.J. (1999) Ammonia Volatilization from Different Fertilizer Sources and Effects of Temperature and Soil pH. Soil Science, 164, 750-758. https://doi.org/10.1097/00010694-199910000-00006

[8] Sheppard, S.C., Bittman, S. and Bruulsema, T.W. (2010) Monthly Ammonia Emissions from Fertilizers in 12 Canadian Ecoregions. Canadian Journal of Soil Science, 90, 113-127. https://doi.org/10.4141/CJSS09006

[9] Smith, K.A. (1997) The Potential for Feedback Effects Induced by Global Warming on Emissions of Nitrous Oxide by Soils. Global Change Biology, 3, 327-338. https://doi.org/10.1046/j.1365-2486.1997.00100.x

[10] Niraula, S., Rahman, S. and Chatterjee, A. (2018) Release of Ammonia and Greenhouse Gases along Moisture Gradient from Manure and Urea Applied Fargo Silty Clay Soil. Applied Engineering in Agriculture, 34, 939-952.

https://doi.org/10.13031/aea.12985

[11] Liu, Y., Wang, C.H., He, N.P., Wen, X.F., Gao, Y., Li, S.G., Niu, S.L., Butterbach-Bahl, K., Luo, Y.Q. and Yu, G.R. (2017) A Global Synthesis of the Rate and Temperature Sensitivity of Soil Nitrogen Mineralization: Latitudinal Patterns and Mechanisms. Global Change Biology, 23, 455-464.

https://doi.org/10.1111/gcb.13372

[12] Nelson, D.W. and Sommers, L.E. (2015) Total Carbon, Organic Carbon, and Organic Matter. In: Methods of Soil Analysis: Part 2 Chemical and Microbiological Properties, 9.2.2, Second Edition, American Society of Agronomy, Inc., Soil Science Society of America, Inc., Madison, 539-579. https://doi.org/10.2134/agronmonogr9.2.2ed.c29

[13] Klute, A. (1986) Water Retention: Laboratory Methods. In: Methods of Soil Analysis. Part 1-Physical and Mineralogical Methods, ASA and SSSA, Madison, 635-662. https://doi.org/10.2136/sssabookser5.1.2ed.c26

[14] Awale, R. and Chatterjee, A. (2017) Enhanced Efficiency Nitrogen Products Influence Ammonia Volatilization and Nitrous Oxide Emission from Two Contrasting Soils. Agronomy Journal, 109, 47-57. https://doi.org/10.2134/agronj2016.04.0219

[15] Liang, L.L., Grantz, D.A. and Jenerette, G.D. (2016) Multivariate Regulation of Soil $\mathrm{CO}_{2}$ and $\mathrm{N}_{2} \mathrm{O}$ Pulse Emissions from Agricultural Soils. Global Change Biology, 22, 1286-1298. https://doi.org/10.1111/gcb.13130

[16] Yadav, D.S., Kumar, V., Singh, M. and Relan, P.S. (1987) Effect of Temperature and Moisture on Kinetics of Urea Hydrolysis and Nitrification. Australian Journal of Soil Research, 25, 185-191. https://doi.org/10.1071/SR9870185

[17] Fenn, L.B. and Kissel, D.E. (1974) Ammonia Volatilization from Surface Applications of Ammonium-Compounds on Calcareous Soils. 2. Effects of Temperature and Rate of Ammonium Nitrogen Application. Soil Science Society of America Journal, 38, 606-610. https://doi.org/10.2136/sssaj1974.03615995003800040025x 